\title{
A STUDY OF DRUG-TAKING AMONG YOUNG PATIENTS ATTENDING A CLINIC FOR VENEREAL DISEASES*
}

\author{
BY \\ ARNOLD LINKEN \\ Fames Pringle House, The Middlesex Hospital, London, W.I
}

In recent years the population attending departments of venereology has been changing in that there has been a marked increase in the younger age groups. The behaviour of young persons has caused concern in most affluent societies through, for instance, the rise in delinquency, the increase in the illegitimate pregnancy rates, the spread of venereal disease, and, of particular significance in this study, the prevalence of drug-taking. The term "behavioural diseases" has been introduced by Burton (1967) of the World Health Organization to illustrate this kind of problem, which impinges upon medical and non-medical disciplines such as psychiatry, venereology and medicine, and sociology and psychology. It was felt that by studying this population when they consult us about one aspect of "behavioural diseases", i.e. venereal infection, further knowledge about other aspects might be forthcoming. Drug-taking was the problem which we chose to study with the co-operation of the young patients attending the Department of Venereology at the Middlesex Hospital.

\section{Drug-Taking in Great Britain}

Figures recently published by the British Home Office showed that there were over 1,300 youngsters known to be dependent on heroin, although a more accurate estimate would probably be as high as 2,000. The incidence of amphetamine abuse, hashish or cannabis smoking, and L.S.D. experiences is unknown, but it can be deduced from the rise in police prosecutions and hospital admissions for drug-induced diseases, that it is high and on the increase.

Only a few epidemiological drug surveys of significance have been undertaken in Great Britain,

\footnotetext{
*Received for publication March 9, 1968.
}

mostly on selected groups. Banks (1960), studying 900 young offenders, noted that 24 per cent. had had a drug experience and 4 per cent. were regular users. Schofield (1965) mentioned in his survey of sexual behaviour in the young that 1 to 3 per cent. of his sample had experienced drug-taking. My own estimates for 1963 to 1966 gathered from a student population showed that 3 to 10 per cent. have had drug experience, but only 0.1 per cent. were dependency risks (Liṇken, 1965, 1966).

The present study was devised with the following aims in mind:

(a) To find out whether patients attending the department of venereology had experience of drug-taking.

(b) To determine whether a self-administered questionnaire would be reliable as a methodological tool.

(c) To decide whether a full-scale project would be informative if the study proved successful.

\section{Method}

252 patients below the age of 30 years were asked whether they had ever taken drugs. Those who replied in the affirmative were given the questionnaire with 23 questions to answer by circling the appropriate response; the form was completed in the waiting room by most, but a few were interviewed and the questionnaire was filled in by the doctor. The information concerned various psycho-social aspects of drug usage and the users themselves. Space was left on the form for comments by the patient.

\section{Results of the Study}

Patient co-operation was excellent but a small number of patients, who were obviously drug-users but were too disturbed to complete the questionnaire, were not included in the survey. Data about 
age, sexual orientation, and promiscuity were obtained from the case records.

As a test of reliability, since it could be assumed that a few patients might boast of drug usagethe "with it" response-the first question "What do you use ?" was given in pharmacological terms, i.e. amphetamines, cannabis, L.S.D., heroin, cocaine, others. The answers showed that most of the patients had a knowledge of drugs. Using pharmacological terms avoided drug-slang which changes rapidly, i.e. reefer is not in general use, being superseded by hash or joint.

Number of Drug-Users 46 out of a total of 252 patients admitted to drug experiences, i.e. 18.2 per cent. of the sample. The number of male drug-users was 26 (15.8 per cent.) of a total of 165 males interviewed. The number of female drugusers was 20 ( 23 per cent.) of a total of 87 females interviewed, a surprisingly high percentage.

Age, Racial Distribution, and Employment of Drug-Users Table I shows that:

(a) The average age of the drug group was 22.9 years for males and 19.2 years for females.

(b) The racial distribution was 72 per cent. U.K. subjects and 28 per cent. overseas patients; the majority of the latter consisted of white Commonwealth subjects, including one Irishman; there was also one Italian, one German, and one West Indian. (c) 88 per cent. of the drug-takers were regularly employed. These included bona fide students, teachers, and lawyers. Only five (12 per cent.) showed employment mobility.

Sexual Orientation of Drug-Users Table I shows that the majority of drug-takers were heterosexual (92 per cent.). The seventeen males were inclined to steady relationships, only five being sexually promiscuous. Only one of the twenty girls was promiscuous. One of the men and one of the girls were married. Only four cases ( 8 per cent.) were homosexually orientated and all were inclined to promiscuous behaviour.

Types of Drugs Used and Types of Users Table I shows that there was a tendency for the group to experiment with a number of drugs. Hashish (cannabis) was the most popular with 32 users; amphetamines (purple hearts, black bombers) had 25 users, L.S.D. 6, and heroin one female user (now "cured" of her dependence).

The users were subdivided into three types. Those with a single experience, those with occasional use, and those with regular use but not necessarily dependent on a drug. 25 per cent. had one experience and nearly 50 per cent. were occasional users, i.e. they took drugs during the weekend or during the evening. A few had used drugs in this way for years. A further 25 per cent. were regular users, including the one female heroin addict, and a male dependent on cannabis ( 2 per cent.). The majority of girls were occasional users.

TABLE I

SEX, AGE, RACE, EMPLOYMENT, SEXUAL ORIENTATION, TYPE OF DRUG USED, AND FREQUENCY OF DRUG-TAKING IN 46 DRUG-USERS.

\begin{tabular}{|c|c|c|c|c|c|}
\hline Sex & & & Male & Female & Total \\
\hline Number of Cases & & & 26 & 20 & 46 \\
\hline Average Age (yrs) & & & $22 \cdot 9$ & $19 \cdot 2$ & $21 \cdot 1$ \\
\hline Nationality & $\begin{array}{l}\text { British } \\
\text { Other }\end{array}$ & & $\begin{array}{r}17 \\
9\end{array}$ & $\begin{array}{r}16 \\
4\end{array}$ & $\begin{array}{l}72 \text { per cent. } \\
28 \text { per cent. }\end{array}$ \\
\hline Employment & $\begin{array}{l}\text { Regular } \\
\text { Occasional }\end{array}$ & & $\begin{array}{r}22 \\
4\end{array}$ & $\begin{array}{r}19 \\
1\end{array}$ & $\begin{array}{l}88 \text { per cent. } \\
12 \text { per cent. }\end{array}$ \\
\hline \multirow{3}{*}{$\begin{array}{l}\text { Sexual } \\
\text { Orientation }\end{array}$} & Heterosexual & $\begin{array}{l}\text { Steady } \\
\text { Promiscuous }\end{array}$ & $\begin{array}{r}17 \\
5\end{array}$ & $\begin{array}{r}19 \\
1\end{array}$ & 92 per cent. \\
\hline & Homosexual & $\begin{array}{l}\text { Steady } \\
\text { Promiscuous }\end{array}$ & $\begin{array}{l}0 \\
4\end{array}$ & $\begin{array}{l}0 \\
0\end{array}$ & 8 per cent. \\
\hline & \multicolumn{2}{|l|}{ Married } & 1 & 1 & \\
\hline Drugs Used & \multicolumn{2}{|l|}{$\begin{array}{l}\text { Amphetamines } \\
\text { Hashish } \\
\text { L.S.D. } \\
\text { Heroin }\end{array}$} & $\begin{array}{r}15 \\
17 \\
3 \\
0\end{array}$ & $\begin{array}{r}10 \\
15 \\
3 \\
1\end{array}$ & $\begin{array}{r}25 \\
32 \\
6 \\
1\end{array}$ \\
\hline Frequency & \multicolumn{2}{|l|}{$\begin{array}{l}\text { Once } \\
\text { Occasional } \\
\text { Regular } \\
\text { Dependent }\end{array}$} & $\begin{array}{r}9 \\
10 \\
6 \\
1\end{array}$ & $\begin{array}{r}2 \\
14 \\
3 \\
1\end{array}$ & $\begin{array}{l}25 \text { per cent. } \\
50 \text { per cent. } \\
25 \text { per cent. }\end{array}$ \\
\hline
\end{tabular}


Questionnaire This was set out in the following form:

(1 a) What do you use ?

(b) How many do you take (inject) in one go?

(2) How often do you use drugs?

(3) How long have you been taking drugs ?

(4) How were you introduced to the drugs?

(5 a) Where were the drugs bought and from whom?

(b) How much did you pay for the drugs?

These questions were aimed at obtaining details of drug usage and social aspects of drug-taking. Some of the answers to this part of the questionnaire were difficult to interpret since the questions tended to enquire into too wide a field of drug usage.

The majority had been introduced to drugs by friends and continued to use drugs bought from friends rather than from drug peddlers or pushers. The price ranged from $1 s$. a tablet of drinamyl to $5 s$. for a "hash" cigarette.

(6) Would you take heroin?

(7) Do you think heroin is harmful ?

Table II shows that 76 per cent. thought that heroin was harmful; three patients stated that it was not harmful, two were uncertain on this point, and six did not complete the question.

(8) Are any of your brothers and sisters taking drugs?

(9) Would you give your teenage brother or sister drugs?
It appeared that three patients had knowledge about their family using drugs. A purpose behind these questions was to elucidate any real anxiety about drug usage. Table II shows that 18 per cent. stated that they would introduce their family to drugs, which gives us some knowledge about the possibility of "contagion".

(10) Do your parents know you use drugs?

30 per cent. stated that their parents knew they took drugs.

(11) Are your parents given drugs by a doctor ?

The question in this form was uninformative since in this context drugs became synonymous with medicines, i.e. some reported that parents were on treatment for hypertension.

(12) Would you drive whilst under the influence of drugs?

One suspected that judgement and skill would be affected under the influence of drugs, although it is common knowledge that racing drivers often use stimulants. Nine were uncertain but three said they would drive under the influence of drugs.

(13) Have you ever been under psychiatric treatment?

Table II shows that 16 per cent. had received psychiatric treatment, but not necessarily for drugtaking.

(14) Have you ever had to see a doctor because of drug-taking.

TABLE II

RESPONSES TO PSYCHO-SOCIAL QUESTIONS

\begin{tabular}{|c|c|c|c|c|c|}
\hline Sex of Patient & & & Male & Female & Total \\
\hline \multirow{7}{*}{$\begin{array}{l}\text { Attitude } \\
\text { to } \\
\text { Drugs }\end{array}$} & \multirow{3}{*}{$\begin{array}{l}\text { (7) Do you think } \\
\text { Heroin is harmful ? }\end{array}$} & No & 1 & 2 & \\
\hline & & Yes & 18 & 17 & 76 per cent. \\
\hline & & Not Sure & 1 & 1 & \\
\hline & \multirow{2}{*}{$\begin{array}{l}\text { (9) Would you give } \\
\text { your teenage brother } \\
\text { or sister drugs? }\end{array}$} & No & 20 & 18 & \\
\hline & & Yes & 6 & 2 & 18 per cent. \\
\hline & \multirow{2}{*}{$\begin{array}{l}\text { (10) Do your parents } \\
\text { know you take drugs? }\end{array}$} & No & 21 & 11 & \\
\hline & & Yes & 5 & 9 & 30 per cent. \\
\hline \multirow[t]{2}{*}{ Psychiatry } & \multirow{2}{*}{$\begin{array}{l}\text { (11) Have you ever been } \\
\text { under psychiatric } \\
\text { treatment? }\end{array}$} & No & 23 & 16 & \\
\hline & & Yes & 3 & 4 & 16 per cent. \\
\hline \multirow[t]{2}{*}{ Delinquency } & \multirow{2}{*}{$\begin{array}{l}\text { (15) Have you ever been } \\
\text { in trouble with the } \\
\text { police? }\end{array}$} & No & 25 & 20 & \\
\hline & & Yes & 1 & 0 & 2 per cent. \\
\hline \multirow{4}{*}{ Sex } & \multirow{2}{*}{$\begin{array}{l}\text { (22) Do drugs alter } \\
\text { your sexual feelings ? }\end{array}$} & Increase & 6 & 0 & \\
\hline & & Decrease & 0 & 9 & \\
\hline & \multirow{2}{*}{$\begin{array}{l}\text { (23) Choice between } \\
\text { sex and drugs }\end{array}$} & Sex & & & \\
\hline & & Drugs & 1 & 4 & \\
\hline
\end{tabular}


Questions 13 and 14 both needed further expansion. Four had seen a doctor specifically about drug-taking.

(15) Have you been in trouble with the police because of drug-taking?

Only 2 per cent. had been in trouble with the police (Table II). The patients in this survey group were not otherwise delinquent in spite of a 12 per cent. employment mobility.

(16) Have you been advised to seek medical advice? There were three who had been advised to seek treatment, but only one had made a step towards consulting his G.P. Unfortunately, the contact who advised them to consult their G.P. was not mentioned.

(17) Do you have a hangover when you come off drugs.

(18) Do you think these drugs might be harmful to you in the future?

Seventeen patients stated that drugs left them with a "hangover"; this is in marked contradiction to the general view amongst adolescents. Nine believed that drugs could be harmful and seven were not certain. However, they often qualified their answers by mentioning which drug they thought was harmful or harmless. Hashish was nearly always noted as being harmless.

(19) What is your alcoholic consumption weekly?

It is widely believed that drugs have replaced alcohol among young people, but sixteen said they were occasional drinkers and six classed themselves as excessive drinkers; four never drank alcohol.

(20) Have you had sexual intercourse?

(21) How old were you when you had sexual intercourse for the first time?

Question 20 was necessary since a number of patients attend clinics for venereal diseases for reassurance. Nobody in this group was a virgin. Nineteen were under 16 when they first had intercourse, 24 were aged 17 to 19, and two were over 20. It appears that members of this group have a tendency to early sexual experiences.

(22) Do drugs affect your sexual potency?

Six men who noted a difference stated that drugs increased their potency (Table II), but nine girls were unanimous in considering that drugs decreased their libido.

(23) If you were given the choice would you prefer a sexual experience to getting "high" on drugs ?

It was interesting to find that four girls preferred drugs to sex.
Patients' Comments on the Investigation These were brief and covered the following points:

(a) Social Concern One felt that drug-taking was a fad and that most youngsters would grow out of it. Others urged relaxation of the law especially over the use of cannabis.

(b) Drug Experiences Four patients expressed the desire to have L.S.D. experience.

(c) Curative Value A number said that drugs helped them to relax and one had been able to cut down excessive drinking of alcohol by the use of hashish. Two others mentioned that they had taken drugs to show friends who were hooked that it was possible to break the habit.

\section{Discussion}

This study has shown that $18 \cdot 2$ per cent. of the young people attending a clinic for venereal diseases in London had experience of drug-taking. This figure is higher than in a student group ( 3 to 10 per cent.), but less than the 24 per cent. in a delinquent group described by Banks (1960). This is possibly a minimal figure because there was some anxiety at the time of the study because of increased police activity, and the same fact might account for the higher percentage of female experimenters. A few other interesting points emerged from this study. There was a preponderance of stable heterosexual relationships, an observation that runs counter to the idea that promiscuous sexual behaviour and drug-taking are synonymous. However, this particular survey group tended to be conventional with only a few delinquents.

The drugs of choice were hashish and amphetamines-often in the form of intravenous methedrine; a few had an L.S.D. experience and 75 per cent. had more than one experience of drug-taking. If the figure of 2 per cent. drug-dependent individuals for a sample of this nature is correct, then the addiction problem amongst adolescents in an urban population may be very serious.

The questionnaire sought and obtained details about how drugs were obtained on the black market, the price, and the place where the drugtaking started. There were signs that members of this group were not absolutely confirmed in their opinions about the dangers of heroin. If this is a trend, educational propaganda in this field is a matter for urgent study. That many of the present generation are confirmed in their notion of the safety of drug-taking is shown by the 18 per cent. who stated that they would probably have introduced their siblings to drugs. 
In a previous paper (Linken, 1966) I have stated that, in my opinion, drug-dependency is associated with an underlying emotional problem. Of this sample 16 per cent. had been under psychiatric care and might be dependency risks at some future date. It was interesting to note that six (13 per cent.) assessed themselves as excessive drinkers. From a practical viewpoint, a counselling service with psychotherapeutic facilities might be a valuable part of a clinic for venereal diseases.

\section{Summary}

It has been shown that $18 \cdot 2$ per cent. of a group of patients under the age of 30 years who are attending a large metropolitan venereal diseases clinic are drug-users.

It was found that the much-maligned questionnaire could be a workable proposition in a busy clinic. It has given information which could lead to an improved drug questionnaire.

It has been demonstrated that patients attending a clinic for venereal diseases are a valuable group to study, especially in obtaining psycho-social information for developing better preventive services in the field of "behavioural diseases".

My thanks are due to the medical, nursing, and administrative staff of James Pringle House for their co-operation with the questionnaire and case material. I should also like to thank Dr R. D. Catterall for allowing me to investigate patients under his care and for his help and advice.

\section{REFERENCES}

Banks, C. (1960). Ford Foundation Research into Young Offenders.

Burton, L. H. J. (1967). Personal communication.

Linken, A. (1965). "Proceedings of Conference on Psychosocial Aspects of Drug Taking". Pergamon Press (Abridged). Society for Study of Addiction, London. (Full Proceedings).

- (1966). "Proceedings of Conference on Epidemiological Aspects of Adolescent Drug Taking". Pergamon Press.

Schofield, M. (1965). "The Sexual Behaviour of Young People". Longmans, London.

Une étude chez les jeunes patients qui visitent un dispensaire anti-vénérien et qui prennent des drogues

RÉSUMÉ

Il a été démontré que 18,2 pour cent d'un groupe de malades âgés de moins de trente ans qui visitent un dispensaire anti-vénérien d'une grande ville prennent des drogues.

On a trouvé que le questionnaire, quoique très critiqué, pourrait être d'une utilité pratique dans un dispensaire très fréquenté.

Il a donné des renseignements qui pourraient mener à une amélioration d'un questionnaire concernent les drogues.

Il a été démontré que les malades visitant un dispensaire anti-vénérien forment un groupe important à être étudié, et peuvent donner surtout des renseignements psycho-sociaux pour le développement d'un meilleur service préventif dans le domaine des maladies de comportement. 